\title{
Roy's Adaptation Model Application in Nursing Care for Pregnant Women With Preeclampsia: Literature Review
}

\author{
Yenny Puspitasari*, Budi Santoso, Nursalam, Agus Sulistyono \\ Doctoral Program in Medical Sciences Faculty of Medicine Universitas Airlangga \\ *yenny_puspita80@yahoo.co.id
}

\begin{abstract}
Contributions to infant mortality from mothers with preeclampsia are enhanced by factors such as the age of the mother, the gestational age and the labor method, and no less important is the model of the orphanage during pregnancy. Incidence of preeclampsia cases is about $5-8 \%$ of all pregnancies. The incidence of the case decreases in the second pregnancy of less than $1 \%$ with normal blood pressure at the first time of pregnancy. This research aims to collect and analyze articles related to the application of nursing model in pregnant women with preeclampsia. The design of the research used is the literature review, articles collected using search engines such as EBSCO, Sciencedirect, Proquest and Elsevier. The article used was published in 2010-2019. Based on the article collected obtained the results that diagnose preeclampsia while pregnant can cause anxiety and fear increases during pregnancy. Because of this condition, individuals have increased blood pressure so as to develop a pathological nature. The role of nurses in providing therapy according to this model is to focus on human beings as a biopsicosocial creature as a unified and interconnected whole. Environmental and family support is very important in this regard. Further studies are advised to consider the effects on various variables by taking into account the random effects and changes in the model with the addition of contextual effects in the analysis.
\end{abstract}

Keywords: Nursing Care Model Application, Pregnant, Preeclampsia 


\section{STRADA Jurnal Ilmiah Kesehatan}

DOI: $10.30994 /$ sjik.v9i2.390

ISSN: 2252-3847 (print); 2614-350X (online)

Vol.9 No.2 November 2020 Page.1545-1551

\section{BACKGROUND}

Pregnancy is associated with significant chronic stress. In complicated pregnancies including preeclampsia, usually indicated by mood and anxiety disorders. Chronic stress is defined here as the cumulative burden of daily mild stress situations and the long-term effects of physiological responses to stress, also known as alostatic loads (Vianna, 2011). Clinical examination in the mother such as blood pressure and urine protein is important during pregnancy. The World Health Organization estimates that about $15 \%$ of all pregnant women will develop into complications related to their pregnancies that can result in maternal and fetal death. Good fetal monitoring is associated with increased morbidity and perinatal mortality, so it is closely related to fetal well-being (RSPAD, 2006).

The physical and psychological stress experienced by preeclampsia patients can cause serious problems, ranging from discomfort to hemodynamic disorders. Physical stress impairs the physical and physiological resilience of patients (Vianna, 2011). Meanwhile, psychological stress causes psychological distress that is responded to by nerves and endocrine, which can result in a negative impact on the patient (Poel, 2009). Psychological stress triggers the hypothalamus secreting corticotropin releasing factor (CRF), in which CRF induces sympathetic nerves that boil in the adrenal medulla, in this case chromafin cells, secreting catecholamines (Ziganshina, 2018). Furthermore catecholamine is captured by $\alpha$ and $\beta$ adrenoeptors in the heart and blood vessels, causing increased ventricular contractions and frequency of heart rate, as well as vasocontriction of blood vessels.

Diseases in pregnancy characterized by the appearance of hypertension and proteinuria are called preeclampsia. Preeclampsia is found at 20 weeks gestation. Preeclampsia is the most common complication in pregnancy, with increasing incidence in the world and related to morbidity and maternal mortality and recorded deaths of approximately 50.000 worldwide or occurring in $2-8 \%$ of pregnancies. In developing countries, preeclampsia causes maternal death (15-20\%) and maternal morbidity (short-term and long-term), perinatal death, premature birth and stunted fetal growth in the uterus (Lasiaprillianty, 2015).

The increasing threat to mothers and babies in increased morbidity and mortality in infants is due to preeclampsia. Factors contributing to infant death from mothers with preeclampsia are maternal age, gestational age and method of delivery (Ernawati et al, 2018). The incidence of preeclampsia is about $5-8 \%$ of all pregnancies, the incidence of preeclampsia in the second pregnancy is less than $1 \%$ of pregnant women with normal blood pressure during the first pregnancy (Kalkunte, 2010). The number of infant deaths fell from 33.278 in 2015 to 32.007 in 2016 and in 2017 there were 10.294 cases. Similarly, maternal mortality rates fell from 4.999 in 2015 to 4.912 in 2016 and in 2017 there were 1.712 cases. Despite the decline, the number is still high (Ernawati et al, 2018).

In preeclampsia nursing care management there is no definitive strategy to prevent preeclampsia limiting the ability of nurses to provide anticipatory guidance and teach patients an evidence-based approach to reducing the risk of preeclampsia through preeclampsia screenning activities, early detection of preeclampsia signs, accurate blood pressure measurement, evaluation of weight changes, surveys and preeclampsia diagnosis, precise referral timing, pharmacological treatment, long-term risk of cardiovascular disease (Approaches and Management) , 2017). Nursing care provided to preeclampsia patients can currently be improved with a supportive-educational system, to treat pregnant women with preeclampsia and fetal health (Shobeiri, 2016).

Various conceptual models of nursing care towards preeclampsia were developed and applied to pregnant women patients, one of which was Roy's adaptation model with the aim of providing support services that pay attention to humans as biopsychosocial beings as a 


\section{STRADA Jurnal Ilmiah Kesehatan}

DOI: $10.30994 /$ sjik.v9i2.390

ISSN: 2252-3847 (print); 2614-350X (online)

Vol.9 No.2 November 2020 Page.1545-1551

whole and interconnected entity. Based on the background above eating the author is interested in discussing "Roy's Adaptation Model in Nursing Care for Pregnant Women with Preectomy".

\section{METHODS}

The method used in writing this article is literature review, which is an international and national literature search conducted using EBSCO, Sciencedirect, Proquest and Elsevier databases. In the early stages of the search for jur $\neg$ nal articles obtained 43,656 articles from 2010-2019 using the keywords "preeclampsia", "preeclampsia in pregnancy", "nursing care in pregnancy" and "roy adaptation model". The number of articles obtained has not been identified and explored its relevance to the compiled articles. Of these only about 92 articles are considered relevant. From the relevant article found 14 articles that have full criteria and quality.

\section{RESULTS}

Based on the results of the article collected by the authors, the authors found that support given to pregnant women with diagnose preeclampsia needs to be improved, not only support in antenatal care, but also support in various pregnancy care. One of the things that can be done is nursing care.

Nursing care shows that nursing care should include services in physical, psychological, social and spiritual form and aims to established patients. This kind of nursing care can also be called a holistic service, where nurses as health workers pay attention to patients from all components such as biological, psychological, social and spiritual (Budiono, 2006).

Physical and psychological stress experienced by preeclampsia patients can cause serious problems, ranging from discomfort to hemodynamic disorders. Physical stress impairs the physical and physiological resilience of patients (Vianna, 2011). Meanwhile, psychological stress causes psychological distress that is responded to by nerves and endocrine, which can have a negative impact (Poel, 2009).

Psychological stress triggers the hypothalamus secreting corticotropin releasing factor (CRF), in which CRF induces sympathetic nerves that boil in the adrenal medulla, in this case chromafin cells, secreting catecholamines (Ziganshina, 2018). Furthermore catecholamine is captured by $\alpha$ and $\beta$ adrenoeptors in the heart and blood vessels, causing increased ventricular contractions and frequency of heart rate, as well as vasocontriction of blood vessels.

Preeclampsia is one of the most challenging pregnancy diseases, with unclear etiology, no specific markers for prediction, and no proper treatment other than referring. Many risk factors have been identified, and diagnostic and management tools have improved over the years. However, preeclampsia is still one of the leading causes of morbidity and maternal mortality worldwide (Costa, 2015).

In pregnant women with preeclampsia experiencing an excessive maternal systemic inflammatory response to pregnancy it has been proposed to be responsible for endothelial dysfunction that causes activation or cellular damage. Endothelial dysfunction is considered central in pathogenesis preeclampsia. The inflammatory process is the adhesion of leukocytes to endothelial cells followed by the transmigration of these cells into perivascular tissue. Endothelial adhesion leukocytes are strongly influenced by the interaction of adhesion molecules and their ligands in these cells. A number of molecules that mediate leukocyte-endothelial adhesion have been identified; these include vascular cellular 


\section{STRADA Jurnal Ilmiah Kesehatan}

DOI: $10.30994 /$ sjik.v9i2.390

ISSN: 2252-3847 (print); 2614-350X (online)

Vol.9 No.2 November 2020 Page.1545-1551

adhesion molecules-1 (VCAM-1), intracellular adhesion molecules-1 (ICAM-1) and Eselection. In vitro studies have shown that the expression of these molecules on the surface of the endothelial is strictly regulated, and that this setting may have an important role in the recovery properties of leukocytes during the inflammatory response. Soluble forms of these molecules can be released into circulation, and increased serum levels of these molecules can indicate endothelial dysfunction. Interestingly, some studies have reported that levels of this adhesion molecule appear to be increasing in the serum of pregnant women with preeclampsia. Indeed, abnormal levels of this adhesion molecule can be considered a marker of preeclampsia. However, reports do not always match the agreement. Lyall et al. reported that serum levels of VCAM-1 and E-selection did not differ significantly between normal pregnancy and preeclampsis. Chaiworapongsa et al. indicates that serum levels of ICAM-1 have no difference between normal pregnancy and preeclampsia (Kim, 2004). The results of the study obtained serum concentrations of dissolved adhesion molecules VCAM-1, ICAM-1 and E-selecin in normal pregnancy and preeclampsia. All three adhesion molecules increase in severe preeclampsia compared to normal pregnancies, and sVCAM-1 among them may be useful in predicting the severity of preeclampsia (Kim, 2004).

\section{DISCUSSION}

Roy's theory of adaptation focuses the approach on three things including focal stimulus, namely stimulus or stimuli that come from within the individual as well as from outside the individual and must be dealt with directly at the same time. Contextual stimulus is all stimulus that affects focal stimulus derived from the surrounding environment, while residual stimulus is a factor derived from the surrounding environment that can have an indirect effect on individuals (Susilowati and Afiyanti, 2013).

Preeclampsia is characterized by the development of hypertension and proteinuria after 20 weeks of pregnancy (Williamson, 2018). This occurs secondaryly due to abnormal placenation at the beginning of pregnancy, due to impaired invasion of the placenta trofoblas and subsequent generations of the ischemic environment. Placental ischemia causes increased oxidative stress of the placenta leading to a syncytiotrophoblast part into the maternal circulation and initiates the maternal inflammatory response of the mother and subsequent endothelial dysfunction (Williamson, 2018).

Psychological function is a supporting factor that increases the risk of pregnant women experiencing hypertension. The results showed that the relationship between psychological function and incidence of hypertension influenced changes to physiological such as the onslence of inflammation, autonomic nerve changes, hypothalamus-pituitary-adrenal activity (Thombre, 2015).

Pregnancy is a unique situation associated with extensive physiological and psychological changes. Changes in appearance prevent many pregnant women from having a positive self-image. In addition to changes in appearance, most pregnant women also have difficulty communicating with others. In other words, women's interpersonal physique and self deteriorate during pregnancy. These problems inflict psychological damage on pregnant women, especially during their first pregnancy. Psychological damage, in turn, is associated with different complications such as high risk for prematurity, premature birth, and cardiovascular disease (Mohammadpour, 2016).

One practical care model that primarily focuses on promoting individual adaptation in unique high pressure situations such as pregnancy is Roy's adaptation model (RAM).

This model can be used by health professionals to promote pregnancy adaptation in women to pregnancy-related problems. According to RAM, adaptation is a series of 


\section{STRADA Jurnal Ilmiah Kesehatan}

DOI: $10.30994 /$ sjik.v9i2.390

ISSN: 2252-3847 (print); 2614-350X (online)

Vol.9 No.2 November 2020 Page.1545-1551

processes in which an individual responds to changes or environmental stimuli. The purpose of nursing interventions in RAM is to improve adaptive response in each of the four physiological modes, self-concepts, interdependence, and role functions.

As one of the adaptive modes in RAM, the concept of self is defined as individual sense of self and influenced by many factors especially the reactions of others. The concept of self consists of three components including the physical self, the personal self, and the interpersonal self. The physical self is the individual perception of his own body, while interpersonal self is the perception of the individual in relation to others. RAM, in particular assesses and focuses on self-concept models and pays special attention to it (Mohammadpour, 2016). RAM has a positive effect on the adaptation of the physical and interpersonal concepts of primigravida women to pregnancy and related problems. Given its simplicity and ease of application, RAM can be used to improve outcomes in pregnancy care (Mohammadpour, 2016).

Roy's adaptation process includes (Philips, 2010) :

\section{Coping mechanism}

In this system there are two mechanisms, namely the first a congenital coping mechanism whose process is unconsciously human, which is genetically determined or generally seen as an automated process on the body. Both coping mechanisms are obtained where the coffee is obtained through the development or experience it learns.

2. Subsystem regulator

It is a co-surgery process that includes the body's subsystems namely nerves, chemical processes, and endocrine systems.

3. Cognator subsystem

The process consists of knowledge and emotion: processing perception and information, learning, consideration, and emotion.

Nurses in providing nursing care to fit the existing problems, it is necessary to choose a theory of approach to nursing care. Roy's theory of adaptation focuses on three things including focal stimulus, namely stimulus or stimuli derived from within the individual as well as from outside the individual and must be dealt with kangsung at the same time. Contextual stimulus is all stimulus that affects focal stimulus derived from the surrounding environment, while residual stimulus is a factor derived from the surrounding environment that can have an indirect effect on individuals (Susilowati and Afiyanti, 2013).

\section{CONCLUSION}

Preeclampsia in pregnancy can cause anxiety and increased fear during pregnancy. Mothers who experience anxiety and stress can cause their blood pressure to rise, putting the mother and baby in danger during pregnancy, even ahead of childbirth.

The physical and psychological stress that pregnant women with preeclampsia can feel will cause problems such as discomfort to the problem of hemodynamic disorders.

At this time nursing care focuses on improving the educational supportive system to preeclampsia patients during pregnancy and fetal health monitoring. In the management of nursing care with preeclampsia did not find definitive strategies to prevent cases of preeclampsia, so the role of nurses is to provide anticipatory guidance and teach patients with various scientific evidence in the process of reducing the risk of preeclampsia so as not to become severe.

Roy's adaptation model is a model that focuses on humans as biopsychosocial beings as a whole and interconnected entity. Nursing care with the application of Roy's adaptation model in reducing the risk of preeclampsia through skrenning preeclampsia activities, signs 


\section{STRADA Jurnal Ilmiah Kesehatan}

DOI: $10.30994 /$ sjik.v9i2.390

ISSN: 2252-3847 (print); 2614-350X (online)

Vol.9 No.2 November 2020 Page.1545-1551

of preeclampsia, accurate blood pressure measurement, evaluation of weight changes, survey and diagnosis of preeclampsia, determination of proper referral, environmental and family support.

Further studies are advised to consider the effects on various variables by taking into account random effects and model changes with the addition of contextual effects in the analysis. For example, the addition of environmental and socio-cultural factors with diverse Indonesian backgrounds related to preeclamsia in pregnancy.

\section{REFERENCES}

Amanak K, Sevil U and Karacam Z. (2019). The Impact of \{renatal Education Based on The Roy Adaptation Model on Gestasional Hypertension, Adaptation to Pregnancy and Pregnancy Outcomes. Journal of The Pakistan Medical Association. Volume 69 Issue 1

Anderson CM and Schmella MJ. (2017). CE: Preeclampsia: Current Approaches to Nursing Mangement. American Journal of Nursing. Volume 117 Issue 11.

Budiono (2016) 'Konsep Dasar Keperawatan'. doi: 10.15713/ins.mmj.3.

Burgess A and Founds S. (2016) Preeclampsia. MCN The American Journal of Maternal/ Child Nursing. Volume 41 Issues 1

Kattah, A. G. and Garovic, V. D. (2014) 'NIH Public Access', 20(3), pp. 229-239. doi: 10.1053/j.ackd.2013.01.014.The.

Lasiaprillianty, I. W. (no date) 'Hubungan IL-10 dengan Serum Kreatinin dan Terjadinya Komplikasi pada Preeklampsia Perawatan Konservatif'.

Lismidiati, W., Santi, N. F. and Akbar, H. W. (2017) 'Pengaruh Self Tapping terhadap Penurunan Level Dysmenorhea pada Mahasiswi Program Studi Ilmu Keperawatan The effect of Self-Tapping on Dysmenorrhea Levels Decrease on Students of Nursing Science Program', Jurnal Keperawatan Padjajaran, 5(1), pp. 57-64.

Mohammadpour, A., Samane, N. and Jahanshir, T. (2016) 'The effects of the roy's adaptation model on primigravida women's self-concept: A randomized controlled trial', Asian Journal of Pharmaceutical Research and Health Care, 8, pp. 17-23. doi: 10.18311/ajprhc/2016/7717.

Nursalam and Kurniawati, N. D. (2007) Model Asuhan Keperawatan pada Pasien HIV/AIDS, Asuhan Keperawatan pada Pasien Terinfeksi HIV/AIDS.

RSPAD. (2006). Standarisasi Pemantauan Kesejahteraan Janin.

Shobeiri, F., Doosti, F., Khodaar, O. and Ali, R.S. (2016) 'The effect of orem's self care model on control of preeclampsia in pregnant women: A randomized clinical trial', Research Journal of Pharmaceutical, Biological and Chemical Sciences.

Sriati, A., Keperawatan, F. and Padjadjaran, U. (no date) 'Pengaruh Sentuhan Spiritual Quantum terhadap Nyeri Saat Perubahan Posisi pada Pasien Paska Operasi di Ruang Perawatan Intensif The Effect of Spiritual Quantum Touch towards Pain after Positioning among Post-Operative Patients in the Intensive Care Unit', 4, pp. 255266.

Susilowati, Y. A. and Afiyanti, Y. (2013) 'Penerapan teori adaptasi roy pada asuhan keperawatan pasien dengan kista ovarium'.

Thombre, M. K., Talge, N. M. and Holzman, C. (2015) 'Association Between PrePregnancy Depression/Anxiety Symptoms and Hypertensive Disorders of Pregnancy', Journal of Women's Health. doi: 10.1089/jwh.2014.4902. 


\section{STRADA Jurnal Ilmiah Kesehatan}

DOI: $10.30994 /$ sjik.v9i2.390

ISSN: 2252-3847 (print); 2614-350X (online)

Vol.9 No.2 November 2020 Page.1545-1551

Townsend, R., O'Brien, P. and Khalil, A. (2016) 'Current best practice in the management of hypertensive disorders in pregnancy', Integrated Blood Pressure Control, 9, pp. 79-94. doi: 10.2147/IBPC.S77344.

Trisiani, D. (2016) Hubungan Kecemasan Ibu Hamil Terhadap Kejadian Preeklampsia di RSUD Majalaya Kabupaten Bandung.

Vianna, P., Bauer, M.E., Dornfeld, D. and Chies, J.A. (2011a and 2011b) 'Distress conditions during pregnancy may lead to pre-eclampsia by increasing cortisol levels and altering lymphocyte sensitivity to glucocorticoids', Medical Hypotheses. doi: 10.1016/j.mehy.2011.04.007.

Wang L, Xing W and Zheng W. (2016). Observation of Personalized Obstetric Care Clinical Intervention on Prinatal Pregnancy-Induced Hypertension. International Journal of Clinical and Experimental Medicine. Volume 9 Issue 11 Article number IJCEM00290099.

Williamson, R. D., McCarthy, C., McCarthym F.P and Kenny, L.C. (2018) 'Exploring the role of mitochondrial dysfunction in the pathophysiology of pre-eclampsia', Pregnancy Hypertension. Elsevier, 13(June), pp. 248-253. doi: 10.1016/j.preghy.2018.06.012.

Williamson, R. D., McCarthy, C., McCarthym F.P and Kenny, L.C. (2017) 'Oxidative stress in pre-eclampsia; have we been looking in the wrong place?', Pregnancy Hypertension. International Society for the Study of Hypertension in Pregnancy, 8, pp. 1-5. doi: 10.1016/j.preghy.2017.01.004. 